\title{
SUBSTANCES RELEASED FROM THE SKIN FOLLOWING THERMAL INJURY. I. HISTAMINE AND PROTEINS ${ }^{1}$
}

\author{
By SOL ROY ROSENTHAL, CHARLES SAMET, RICHARD J. WINZLER, AND \\ SELWYN SHKOLNIK \\ (From the Institution for Tuberculosis Research of the University of Illinois and the Departments \\ of Preventive Medicine and Biochemistry, University of Illinois College of Medicine, \\ Chicago, Ill.)
}

(Submitted for publication February 23, 1956; accepted September 24, 1956)

The nature of the substances released from the skin following burning is not known. The majority of the studies concerned with this problem have involved analyses of blood or the lymph draining the burned part, and have been complicated by the complex composition of the blood and lymph and the complex interrelation between different tissues. The present studies represent an attempt to simplify the problem by employing excised skin and collecting the materials diffusing into a saline solution following exposure to hot water.

\section{METHODS}

\section{Preparation of diffusates}

Mongrel dogs were anesthetized with Nembutal ${ }^{\circledR}$ (30 mg. per kilo) and the skin of their backs was clipped with an Oster No. 40 hair clipper. By the use of an electrically driven dermatome ${ }^{2}$ set at .015 inch, split thicknesses of $\operatorname{skin}^{3} 3$ in. wide and up to 12 in. long were obtained. The slices were placed immediately on salinesoaked gauze, cut up into $3-\mathrm{cm}$. squares, and secured with the cut surface inward about one end of glass cylinders, $2.4 \mathrm{~cm}$. in diameter (Figure 1). The cut surface was in continuity with the inside of the cylinder. Before the burning, the cut surface was washed three times with 5 to $10 \mathrm{ml}$. of saline, and after the final washing, $2 \mathrm{ml}$. of saline were allowed to remain inside of the cylinder. Burning was done in hot water contained in a tray which held a U-shaped metal rack that supported the tubes in such a manner that only the skin was submerged in water (Figure 2). After burning at various temperatures and for various periods of time, the fluid was allowed to remain in the cylinder for 5 minutes while submerged in water at $37^{\circ} \mathrm{C}$. This fluid was then collected, examined separately or pooled. Control samples were obtained

1 These studies were aided by a contract between the Office of Naval Research, Department of the Navy, and University of Illinois, NR 114-161.

2 Brown electro-dermatome, Zimer Mfg. Co., Warsaw, Indiana.

3 The cut of the skin as noted by microscopic section was slightly below the rete pegs and included about half of the reticulum layer of the cutis. from unburned skin following immersion for 5 minutes at $37^{\circ} \mathrm{C}$. All experiments were complete within a half hour after the skin sections were prepared. Cooling of the skin with ice was avoided. The pooled material was immediately frozen and was kept in this state or was lyophilized for future use.

\section{RESULTS}

The following are some of the components identified in the diffusates:

\section{Histamine}

The histamine content of the diffusates was determined essentially by the method of Schultz and Dale $(1,2)$ using guinea pig ileum suspended in a 4-ml. bath. All values are expressed as micrograms of histamine per sample following the burning of a $4.5 \mathrm{sq} . \mathrm{cm}$. piece of skin. With rare exceptions, a minimum of 3 individual samples was averaged for each experimental condition. Corrections were made for volume changes due to evaporation during heating.

Figure 3 shows the histamine released into the diffusate after exposure to various temperatures for 30 seconds to 20 minutes. It is seen that there

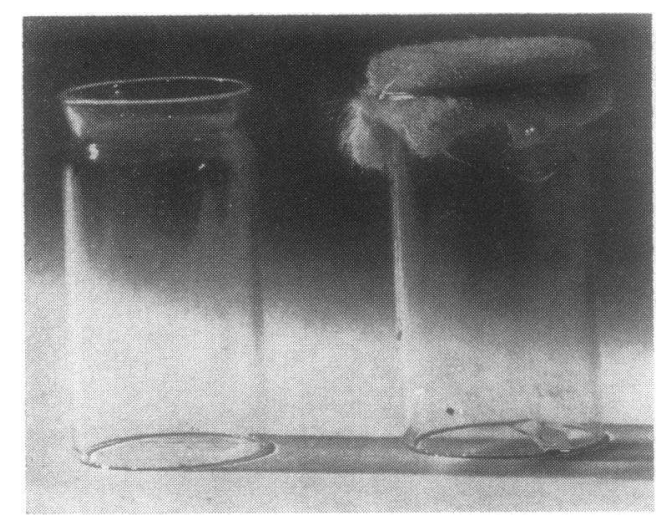

Fig. 1. Glass Cylinders With and Without Skin in Place (7/8 Size) 


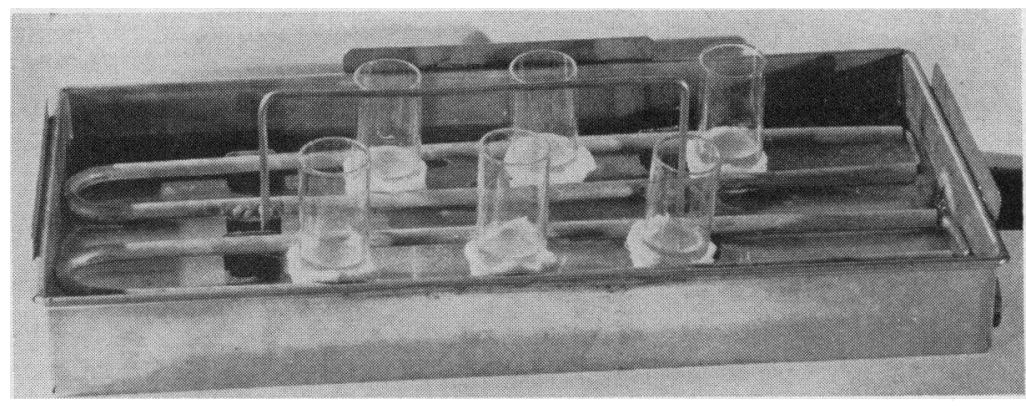

Fig. 2. Rack Holding Skin Preparations in Place

Burning of skin is accomplished by submerging skin in hot water of pan.

is a direct relationship between the temperature and time of burning and the extent of histamine release for the first two minutes of burning. Detectable amounts of histamine were released after 15 seconds of burning at $96^{\circ} \mathrm{C}$ and $85^{\circ} \mathrm{C}, 45 \mathrm{sec}-$ onds at $75^{\circ} \mathrm{C}$, and 2 minutes at $55^{\circ} \mathrm{C}$. Only trace amounts of histamine were released after exposure to $47^{\circ} \mathrm{C}$ for periods of 1 to 10 minutes (in one of six experiments, $.004 \gamma$ of histamine was released after 1,3 and 5 minutes of burning). . At temperatures of $85^{\circ} \mathrm{C}$ and $96^{\circ} \mathrm{C}$ for 5 minutes and more of burning, the values fall below the amounts obtained at $65^{\circ} \mathrm{C}$ or $75^{\circ} \mathrm{C}$.

The non-specificity of the guinea pig ileum for histamine raised the possibility that the active substance was a compound other than histamine. That the substance in question was histamine was supported by the fact that the action on the guinea pig intestine was prevented by first adding the antihistamine, thymoxyethyldiethylamine $(4 \mu \mathrm{gm}$. per ml.), to the bath. Contraction of the muscle strip caused by the diffusate was not inhibited by atropine, thus eliminating acetylcholine as the active component. Intravenous injection of the diffusates in dogs produced a fall in blood pressure equivalent to the amount of histamine present in the diffusates, this effect was also inhibited by thymoxyethyldiethylamine ( $40 \mathrm{mg}$. per kilo) subcutaneously one-half hour before testing.

The non-dialyzable portion of diffusates, dialyzed 24 hours against distilled water, failed to cause a drop of blood pressure in the dog.

\section{Proteins}

The amount of protein released in the diffusate was measured by the biuret method (Mehl [3]). Values are expressed as milligrams per sample (4.5 sq. cm. of skin) corrected by the values obtained from the unburned control skin. Each

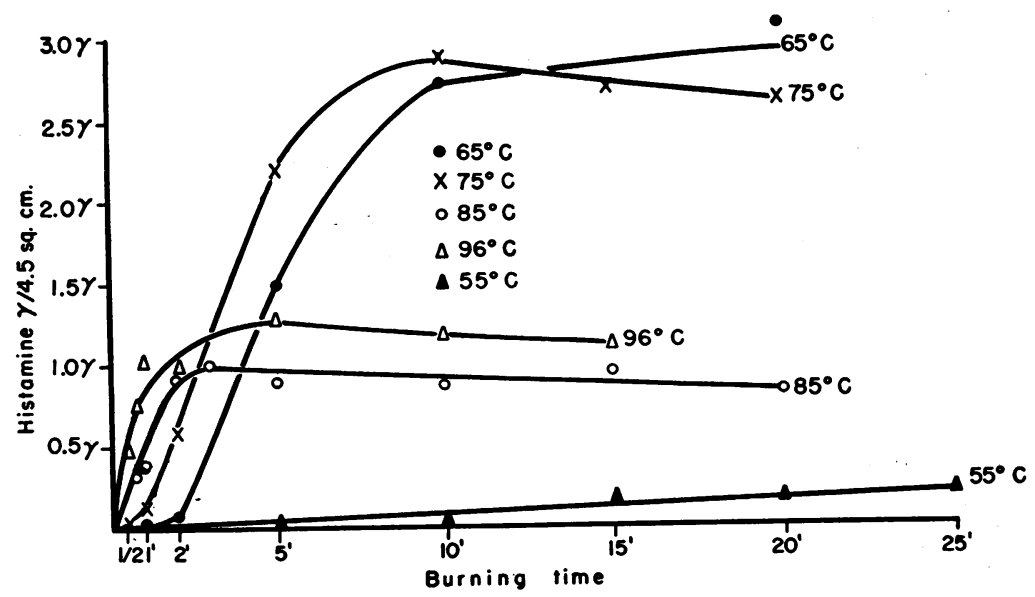

Fig. 3. Histamine Released from Burned Dog Skin After Exposure to Various Temperatures for Varying Periods of Time

Each point is the average of at least 3 separate experiments. 


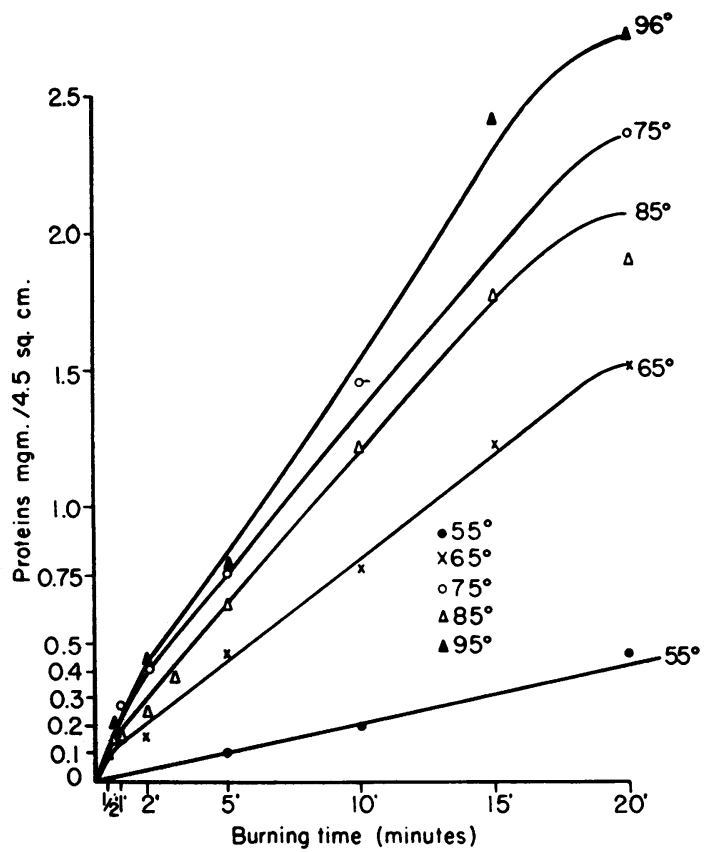

Fig. 4. Protein Release After Exposure to Various Temperatures for Varying Periods of Time (BIURET METHOD)

Each point is the average of at least three separate experiments.

point on the curves (Figure 4) is an average of at least three separate experiments.

Figure 4 shows the relation of temperature and duration of burning to the amount of protein released. The amount of protein released from the dog skin was directly related to the temperature and the duration of injury (up to $20 \mathrm{~min}$.). For temperatures of $75^{\circ} \mathrm{C}, 85^{\circ} \mathrm{C}$ and $96^{\circ} \mathrm{C}$, the protein values approximated each other. After 20 minutes of burning at these high temperatures, the rate of protein release decreases. Under these conditions, coagulation was noted in the diffusates especially for those exposed to $96^{\circ} \mathrm{C}$. At $47^{\circ} \mathrm{C}$ detectable protein was noted in only one of six experiments.

\section{Nature of protein released}

The question of the nature of the protein or protein split products released into the diffusate of control and burned skin was examined by several methods. The diffusates were collected from 20 to 100 similar experiments, the samples pooled, dialyzed for 48 hours against distilled water, lyophilized, and the residue weighed.
The results of these determinations are shown in column 2 of Table I. The amount of nondialyzable material increases from $0.27 \mathrm{mg}$. per sample ( $4.5 \mathrm{sq} . \mathrm{cm}$. of skin) in the control to 13.6 mg. per sample in the skin exposed to $96^{\circ} \mathrm{C}$ for 15 minutes. The values obtained by this method are appreciably higher than those obtained by the biuret method employing single samples (Figure 4). The reason for this difference is not clear.

The electrophoretic behavior of the materials was examined after dialysis and lyophilization. Electrophoresis was carried out at $\mathrm{pH} 8.6$ in $0.1 \mathrm{M}$ veronal buffer at $10^{\circ} \mathrm{C}$, using the Antweiler microelectrophoresis apparatus and photographing the Schlieren patterns.

The control sample showed the presence of three major components with mobilities corresponding to serum albumin, $\beta$ globulin, and a very small amount of a protein with the mobility of $\gamma$ globulin (slow component). All burned samples showed markedly decreased proportions of the fast moving components and increased amounts of components having the low mobility corresponding to that of $\gamma$ globulin. In some cases this slow component appeared as a single electrophoretic component, whereas in other cases it was distinctly heterogeneous. Some typical electrophoretic patterns are shown in Figure 5. Electrophoretic results are summarized in column 3 of Table I. These data show that the protein liberated into the diffusate after exposure to heat is largely of a type having a very low electrophoretic mobility, and differs from the proteins present in the control samples.

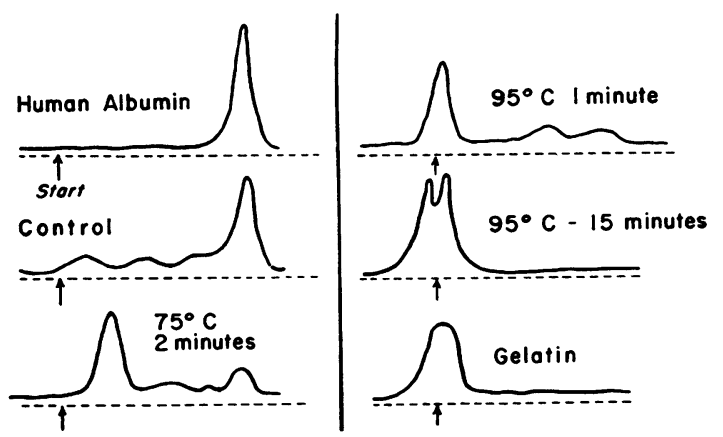

Fig. 5. Electrophoretic Patterns of Diffusates from Burned Skin and Controls

Antweiler microelectrophoretic apparatus at $\mathrm{pH} 8.6$ in $0.1 \mathrm{M}$ veronal buffer at $10^{\circ} \mathrm{C}$. Starting boundary indicated by arrows. Time, 10 minutes. Movement to the right is toward the anode. 
TABLE I

The nature of the proteins released from burned dog skin *

\begin{tabular}{|c|c|c|c|c|c|c|c|c|c|}
\hline \multirow[b]{2}{*}{ Proteins } & \multirow{2}{*}{$\begin{array}{c}2 \\
\text { Protein } \\
\text { per } \\
\text { sample } \\
\text { (mg. dry wot.) }\end{array}$} & \multicolumn{2}{|c|}{$\begin{array}{c}3 \\
\text { Micro- } \\
\text { electrophoresis }\end{array}$} & \multirow{2}{*}{4} & \multirow{2}{*}{$\underset{\%}{\text { Gelatint }}$} & \multirow{2}{*}{$\begin{array}{c}6 \\
\substack{\text { Hexose } \\
\%}\end{array}$} & \multirow{2}{*}{$\begin{array}{c}7 \\
\text { Hexose } \\
\text { in non- } \\
\text { gelatin } \\
\text { protein } \ddagger \\
\%\end{array}$} & \multirow{2}{*}{$\begin{array}{c}8 \\
\text { Sialic } \\
\text { acid§ } \\
\%\end{array}$} & \multirow{2}{*}{$\begin{array}{c}\text { Sialic } \\
\text { acid in } \\
\text { non-gelatin } \\
\text { protein } \\
\%\end{array}$} \\
\hline & & Comp. & $\%$ & & & & & & \\
\hline Control & 0.27 & $\begin{array}{l}\text { Alb- } \alpha \text { glob. } \\
\beta \text { glob. } \\
\gamma \text { glob. }\end{array}$ & $\begin{array}{l}50 \\
40 \\
10\end{array}$ & 0.15 & 0.6 & 1.82 & 1.82 & 3.51 & 3.51 \\
\hline $75^{\circ} \mathrm{C}-2 \mathrm{~min}$. & - & $\begin{array}{l}\text { Alb- } \alpha \text { glob. } \\
\beta \text { glob. } \\
\gamma \text { glob. }\end{array}$ & $\begin{array}{l}30 \\
10 \\
60\end{array}$ & & & & & & \\
\hline $96^{\circ} \mathrm{C}-1 \mathrm{~min}$. & 0.84 & $\begin{array}{l}\text { Alb- } \alpha \text { glob. } \\
\beta \text { glob. } \\
\gamma \text { glob. }\end{array}$ & $\begin{array}{l}40 \\
10 \\
50\end{array}$ & 1.45 & 10.8 & 3.84 & 4.3 & 3.09 & 3.29 \\
\hline $96^{\circ} \mathrm{C}-15 \mathrm{~min}$. & 13.6 & $\begin{array}{l}\text { Alb- } \alpha \text { glob. } \\
\beta \text { glob. } \\
\gamma \text { glob. }\end{array}$ & $\begin{array}{r}5 \\
0 \\
95\end{array}$ & 10.3 & 84.7 & 1.29 & 5.1 & 0.89 & 4.95 \\
\hline Gelatin & - & $\begin{array}{l}\text { Alb- } \alpha \text { glob. } \\
\beta \text { glob. } \\
\gamma \text { glob. }\end{array}$ & $\begin{array}{r}0 \\
0 \\
100\end{array}$ & 12.0 & 100.0 & 0.58 & & 0.16 & \\
\hline Serum albumin & - & $\begin{array}{l}\text { Alb- } \alpha \text { glob. } \\
\beta \text { glob. } \\
\gamma \text { glob. }\end{array}$ & $\begin{array}{r}100 \\
0 \\
0\end{array}$ & 0.07 & 0 & 0.1 & & 0.10 & \\
\hline
\end{tabular}

* Each value is the average of replicate determinations on two separate preparations which were usually in close agreement.

$\dagger$ Calculated on the basis that albumin contains 0.07 per cent hydroxyproline and gelatin contains 12.0 per cent. $¥$ Calculated on the basis that gelatin contains 0.58 per cent carbohydrate.

Referral to a crystalline sample of "sialic acid" obtained from Blix at Upsala, Sweden.

It appeared possible that the slow moving components appearing in the diffusate might be gelatin, produced by the thermal degradation of collagen. Electrophoretic studies on gelatin (Table I) indicated that gelatin migrates very slowly in the microelectrophoresis apparatus. Further evidence that gelatin is the major protein in the diffusates from burned skin was obtained by carrying out determinations of hydroxyproline in the proteins isolated from the diffusates. Since collagen is the only tissue protein which contains large amounts of hydroxyproline, an estimate of the gelatin content of the fractions can be calculated from their hydroxyproline content.

Determinations of hydroxyproline were carried out by the method of Neuman and Logan (4). Calculation of the gelatin content of the proteins in the diffusates was made on the basis that albumin contained 0.07 per cent hydroxyproline and that gelatin contained 12 per cent. The results of these analyses, given in columns 4 and 5 of Table I, show that the control samples contained little hydroxyproline corresponding to less than 0.6 per cent gelatin. The samples heated at $96^{\circ} \mathrm{C}$ for 1 minute contained considerable gelatin and the samples heated at $96^{\circ} \mathrm{C}$ for 15 minutes consisted largely of this protein. Consequently, it can be concluded that a major part of the protein released into the diffusate upon exposure to heat is due to the thermal decomposition of collagen.

It is clear, however, that gelatin was not the only protein released from the tissue on burning. Were this the case, the gelatin content of the $96^{\circ} \mathrm{C}$ -1-minute samples should be 68 per cent, and of the $96^{\circ} \mathrm{C}-15$-minute samples, 98 per cent, based on the increased protein content of the samples (column 2 of Table I). Consequently, other proteins were released as a result of heating, since the hydroxyproline content was less than that expected if all of the increased protein were gelatin.

It appeared possible that there might have been a depolymerization of mucoproteins and mucopolysaccharides of the skin as a result of thermal injury, and that some of these components might appear in the diffusates. In order to investigate this possibility, determination of the carbohydrate 
content of the proteins isolated from the diffusates was carried out using the orcinol method of Sørensen and Haugaard (5). The results obtained are shown in column 6 of Table I. Since gelatin contains only 0.58 per cent carbohydrate, it is clear that a considerable amount of carbohydrate-rich protein was liberated into the diffusate as a result of heating. By subtracting the carbohydrate content of the gelatin, it is possible to calculate indirectly the carbohydrate content of the non-gelatin proteins present in each fraction. The results of this calculation are shown in column 7 of Table I. There is present protein with an average carbohydrate content of 4.3 per cent in the $96^{\circ} \mathrm{C}$ for 1 -minute, and 5.1 per cent in the $96^{\circ} \mathrm{C}$ for 15 -minute samples. These values are sufficiently high to indicate that carbohydrate-rich proteins are liberated as a result of thermal injury.

Further evidence that glycoproteins are liberated was obtained by assaying the proteins isolated from the diffusates for "sialic acid," a compound of unknown structure frequently associated with glycoproteins (Winzler [6]). For this purpose the p-dimethylamino-benzaldehyde method as described by Werner and Odin was used (7). The results of these analyses are shown in column 8 of Table I. The "sialic acid" content of the nongelatin proteins is given in column 9 of Table I. These data also show that proteins relatively rich in "sialic acid" are released into the diffusate following thermal injury.

\section{DISCUSSION}

A major advantage of the method described is that it permits the direct detection of substances released from the skin as a result of burning or other stimuli. This method was first described in conjunction with the studies done on the mechanism of pain by Rosenthal and Minard (8). By this method it was shown that mechanical, electrical or thermal stimulation of the epidermis of the skin was followed by release of histamine in direct relation to the degree of the stimulus (9). The present modification uses an electrically driven dermatome which makes it possible to obtain a uniform split thickness of skin and facilitates the obtaining of large skin samples. Since much pressure is applied in obtaining these skin samples, the area is practically bloodless.

Histamine or a histamine-like substance has been found in the blood of shoats, pigs, guinea pigs, and humans following burning (10-12). It is likely from the present and other studies that skin is one source of this histamine. Harris (13), for example, found as much as $10 \mathrm{mg}$. of histamine per kilogram of human skin.

Following burning of the skin, proteins and protein split products are released from the skin. These materials are undoubtedly absorbed into the general circulation in burned animals. For example, a slow moving component which migrates with half the speed of gamma globulin was found in the lymph draining the scalded leg of calves but not in the serum by Perlmann, Glenn, and Kaufman (14). In the light of the present experiments it appears likely that this component was gelatin. A marked increase in nitrogenous material is noted in the blood following burning, both in experimental animals by Braasch, Bell, and Levenson (15) and in human beings by Taylor, Levenson, Davidson, and Adams (16). However, the nature and the source of this material has not yet been determined (Walker [17] and Rosenthal and McCarthy [18]).

There are two phases during which proteins and protein split products are released from the skin following scalding. The initial phase extends over the burning period while the second phase covers the period following the burning. The results described in this paper refer to the initial phase only. It has been shown by Ungar and Damgaard (19), using skin slices of the guinea pig, that the release of protein split products during the initial phase is not due to proteolytic action. The process proceeds at a fast rate at temperatures at which known proteases are destroyed and, furthermore, enzymatic inhibitors such as $\mathrm{CuSO}_{4}$ and $\mathrm{HgCl}_{2}$ fail to inhibit the release of protein products.

During the secondary phase of burning proteolysis is probably enzymatic in nature. It is inhibited partially by anti-proteases such as soy bean inhibitor and sodium salicylate (19).

\section{SUMMARY}

A method was developed for obtaining diffusates from excised dog skin after in vitro exposure to burning (scalding). It was found that exposure to heat caused a liberation of histamine or histaminelike substance into the diffusates. The amount of 
histamine liberated depended upon the time and the temperature to which the excised skin was exposed to the injury. The greatest amount of histamine was released after exposure to $65^{\circ} \mathrm{C}$ and $75^{\circ} \mathrm{C}$ for 20 minutes. The lowest temperature consistently causing histamine release was $55^{\circ} \mathrm{C}$ for 2 minutes. The release of protein was increased with the time and temperature of burning. Determination of the hydroxyproline content and the electrophoretic behavior of such preparations indicated that the major portion of the proteins released, particularly at high temperatures and for prolonged periods, resembled gelatin. In addition, smaller amounts of other proteins containing appreciable amounts of hexose and "sialic acid" were released.

\section{REFERENCES}

1. Schultz, W. H., Physiological studies in anaphylaxis. 1. The reaction of smooth muscle of the guinea pig sensitized with horse serum. J. Pharmacol. \& Exper. Therap., 1910, 1, 549.

2. Dale, H. H., The anaphylactic reaction of plain muscle in the guinea-pig. J. Pharmacol. \& Exper. Therap., 1913, 4, 167.

3. Mehl, J. W., The biuret reaction of proteins in the presence of ethylene glycol. J. Biol. Chem., 1945, 157, 173.

4. Neuman, R. E., and Logan, M. A., The determination of hydroxyproline. J. Biol. Chem., 1950, 184, 299.

5. Sфrensen, M., and Haugaard, G., Uber die Anwendbarkeit der Orcinreaktion zur Bestimmung der Art und Menge von Kohlenhydratgruppen in Eiweisstoffen. Biochem. Ztschr., 1933, 260, 247.

6. Winzler, R. J., Determination of serum glycoproteins in Methods of Biochemical Analysis, Ed. by B. Glick, New York, Interscience, 1955, 2, 279.
7. Werner, I., and Odin, L., On the presence of sialic acid in certain glycoproteins and in gangliosides. Acta Soc. med., Upsala, 1952, 57, 230.

8. Rosenthal, S. R., and Minard, D., Experiments on histamine as the chemical mediator for cutaneous pain. J. Exper. Med., 1939, 70, 415.

9. Lambert, E., and Rosenthal, S. R., Study of skin histamine (with some results of splanchnic nerve stimulation). Proc. Soc. Exper. Biol. \& Med., 1943, 52, 302.

10. Rosenthal, S. R., The toxin of burns. Ann. Surg., 1937, 106, 111.

11. Rose, B., and Browne, J. S. L., Studies in blood histamine in cases of burns. Ann. Surg., 1942, 115, 390.

12. Behrmann, V. G., Schelling, V., and Hartman, F. W., Blood histamine levels in experimental burns. Am. J. Physiol., 1945, 145, 483.

13. Harris, K. E., Observations upon a histamine-like substance in skin extracts. Heart, 1927, 14, 161.

14. Perlmann, G. E., Glenn, W. W. L., and Kaufman, D., Changes in the electrophoretic pattern in lymph and serum in experimental burns. J. Clin. Invest., 1943, 22, 627.

15. Braasch, J. W., Bell, J., and Levenson, S. M., Excretion of nitrogen and electrolytes following thermal burns in the rat. Surgery, 1950, 27, 743.

16. Taylor, F. H., Levenson, S. M., Davidson, C. S., and Adams, M. A., Abnormal nitrogen metabolism in patients with thermal burns. New England J. Med., 1943, 229, 855.

17. Walker, J., Jr., Changes in non-protein fractions of the plasma nitrogen following extensive thermal burns. Am. J. M. Sc., 1945, 209, 413.

18. Rosenthal, O., and McCarthy, M. D., Post-burn azotemia, its characteristics and relationship to severity of thermal injury. Am. J. Physiol., 1947, 148, 365.

19. Ungar, G., and Damgaard, E., Protein breakdown in thermal injury. Proc. Soc. Exper. Biol. \& Med., 1954, 87, 378.

\section{SPECIAL NOTICE TO SUBSCRIBERS}

Post Offices will no longer forward the Journal when you move.

Please notify The Journal of Clinical Investigation, Business Office, 622 West 168th Street, New York 32, N. Y. at once when you have a change of address, and do not omit the zone number if there is one. 